\title{
River Styles and stream power analysis reveal the diversity of fluvial morphology in a Philippine tropical catchment
}

\author{
Pamela Louise M. Tolentino ${ }^{1,2^{*}}$ (D) John Edward G. Perez ${ }^{1,3}$, Esmael L. Guardian ${ }^{1}$, Richard J. Boothroyd ${ }^{2}$, \\ Trevor B. Hoey ${ }^{4}$, Richard D. Williams ${ }^{2}$, Kirstie A. Fryirs ${ }^{5}$, Gary J. Brierley ${ }^{6}$ and Carlos Primo C. David ${ }^{1}$
}

\begin{abstract}
Characterisation of hydromorphological attributes is crucial for effective river management. Such information is often overlooked in tropical regions such as the Philippines where river management strategies mainly focus on issues around water quality and quantity. We address this knowledge gap using the River Styles Framework as a template to identify the diversity of river morphodynamics. We identify eight distinct River Styles (river types) in the Bislak catchment $\left(586 \mathrm{~km}^{2}\right)$ in the Philippines, showing considerable geomorphic diversity within a relatively small catchment area. Three River Styles in a Confined valley setting occupy 57\% of the catchment area, another three in a partly confined valley setting occupy $37 \%$, and two in the remaining $6 \%$ are found in a laterally unconfined valley setting. Five characteristic downstream patterns of River Styles were identified across the catchment. We observe that variation in channel slope for a given catchment area (i.e., total stream power) is insufficient to differentiate between river types. Hence, topographic analyses should be complemented with broader framed, catchment-specific approaches to river characterisation. The outputs and understandings from the geomorphic analysis of rivers undertaken in this study can support river management applications by explicitly incorporating understandings of river diversity and dynamics. This has the potential to reshape how river management is undertaken, to shift from reactive, engineering-based approaches that dominate in the Philippines, to more sustainable, ecosystem-based approaches to management.
\end{abstract}

Keywords: Tropical river, Topographic controls, River Styles, Catchment, River management, Fluvial geomorphology

\section{Introduction}

Recognition of morphological diversity and understanding of river processes (dynamics) are essential for effective river management (Brierley and Fryirs 2005; Gurnell et al. 2015; Rinaldi et al. 2016; Hohensinner et al. 2018). Differences between rivers are often contextualised at the reach scale $\left(10^{-1}-10^{1} \mathrm{~km}\right.$; Belletti et al. 2017) where geomorphic structure and function are approximately uniform, determined by a set of boundary conditions within which the river operates (Frissell et al. 1986; Brierley and Fryirs 2005; Wyrick and Pasternack 2014).

*Correspondence: Pammie.Tolentino@glasgow.ac.uk

${ }^{1}$ University of the Philippines-Diliman, Quezon City, Philippines

Full list of author information is available at the end of the article
Imposed boundary conditions (i.e., geological and terrain controls) dictate the valley setting and topography of the landscape within which rivers adjust, while flux boundary conditions such as the interaction of water discharge and sediment transport induce reach-scale variability in morphodynamics (Brierley and Fryirs 2005). Alterations to flux boundary conditions, including human-induced pressures and disturbances to water and sediment flows, may irreversibly impact fluvial systems (Rhoads 2020). Integrating principles from hydrology, geomorphology, and ecology strengthen the potential of development of sustainable river management programs (Brierley 2008; Brierley et al. 2019). This requires detailed information of river morphological diversity across multiple spatiotemporal scales (Gurnell et al. 2015). 
A range of classification schemes has been developed to assess river morphological diversity. Generally, these schemes seek to categorise reaches by grouping similar process and form characteristics. Classification schemes vary in their approach, the environment for which they were developed, and the spatiotemporal scales over which they are applied (Kondolf et al. 2003; Buffington and Montgomery 2013). However, Kasprak et al. (2016) demonstrate that the underlying principles and premises of such geomorphological analyses are inherently consistent, with different approaches generating similar outputs (i.e., maps of river type). Classification based on hydrology and river geomorphology (hydromorphology) often provides a first step in the analysis of river systems (Fuller et al. 2013), and is a fundamental starting-point when integrating interdisciplinary components of analysis (e.g., Sear et al. 1995; Gilvear 1999; Kondolf et al. 2003; Downs and Gregory 2004; Brierley and Fryirs 2005; Brierley 2008; Meitzen et al. 2013; Tadaki et al. 2014; Rinaldi et al. 2016; Dallaire et al. 2019).

Spatially hierarchical classification frameworks support river management strategies, including those to maintain ecosystem functions (Dollar et al. 2007; Beechie et al. 2010), to mitigate the effects of flood hazards (Rinaldi et al. 2013, 2015), and to restore degraded rivers (Beechie et al. 2010; Hawley 2018). These frameworks use a nested spatial hierarchy to organise and structure complex river systems, wherein large-scale features (i.e., a river) are subdivided into sequentially smaller features (e.g., segment to river reach to geomorphic unit/s to microhabitat subsystems; Frissell et al. 1986). The River Styles Framework developed by Brierley and Fryirs (2005) incorporates spatially-hierarchical geomorphic analyses within a catchment-based approach to river management. Knowledge of changes in the catchment (historical and contemporary, from upstream to downstream) is essential to contextualise river adjustment (e.g., lateral, vertical and wholesale) (Brierley and Fryirs 2009), especially as disturbances caused by natural phenomenon and anthropogenic activities may occur anytime and at any position in a catchment (Gurnell et al. 2015). The River Styles Framework provides a set of consistent and generic procedures and guidelines for river assessment that can be applied at local to regional scales (e.g., Kuo and Brierley 2013; Marcal et al. 2017; Khan et al. 2021; Nardini et al. 2020). The framework has four stages: Stage One involves identifying and characterising River Styles; Stage Two uses geomorphic principles to assess evolution, and river condition; Stage Three assesses river recovery potential; Stage Four sets target conditions and priorities to realise effective river management (Brierley and Fryirs 2005).

While the River Styles Framework has been used to support river management in a variety of locations, there has been limited application in tropical regions (Fryirs and Brierley 2021). Tropical rivers exhibit a variety of morphological forms (Latrubesse et al. 2005) and significant geomorphic diversity (Sinha and Latrubesse 2020). Taking examples from across the Philippines, remote sensing analyses have indicated the dynamic planform morphologies of selected rivers. Reach-scale aerial imagery analysis in the Bucao and Santo Tomas Rivers (Zambales) showed spatially variable changes in river width between 2004 and 2013; a legacy effect of sediment supply from the Mt Pinatubo volcanic eruption in 1991 (Paz-Alberto et al. 2016). A national-scale assessment of river migration in the vicinity of 74 large river bridges using Landsat satellite imagery showed that some river reaches have remained approximately stable over the 30-year monitoring period whilst others have considerably adjusted through migration, contraction and expansion (Boothroyd et al. 2021b). River migration rates $>300 \mathrm{~m}$ per decade have been quantified along a $\sim 85 \mathrm{~km}$ segment of the Cagayan River; these migration rates are typically higher than those observed in temperate rivers (Dingle et al. 2019) and can present a challenge for river management.

Rivers in the Philippines play a central role in the community (Fig. 1a), providing economic benefits such as agriculture on floodplains (Fig. 1b), fishing pens in channels (Fig. 1c, and gravel mining on riverbeds and bars (Fig. 1d). While some anthropogenic activities are temporary and have a limited impact on river form and function, the construction of large anthropogenic structures including dams, bridges and embankments (Fig. 1e-g) imposes a particular width and/or alignment on the channel. These structures restrict the capacity for adjustment, effectively 'fighting' against the prevailing river behaviour (Brierley and Fryirs 2009).

Despite the importance of river morphological characteristics and their associated processes, this information is not routinely considered in the classification of water bodies in the Philippines. Instead, the classification is primarily based on water quality standards set by the Department of Environment and Natural Resources (DENR Administrative Order 2016-08) (DENREMB 2016). Furthermore, river basin management plans exist for the major catchments only (drainage area $>3000 \mathrm{~km}^{2}$ ). Although some data on physiography, climate, geology, and land use exist, analyses on fluvial geomorphological detail (i.e., stream network characteristics, geomorphic units, bed material, sediment, and flow regime) are often lacking. As the result of the gaps in hydromorphological understanding in the catchment management plans, interventions tend to be limited to local and reactive approach such as misplaced dikes and river training measures that are expensive to build 

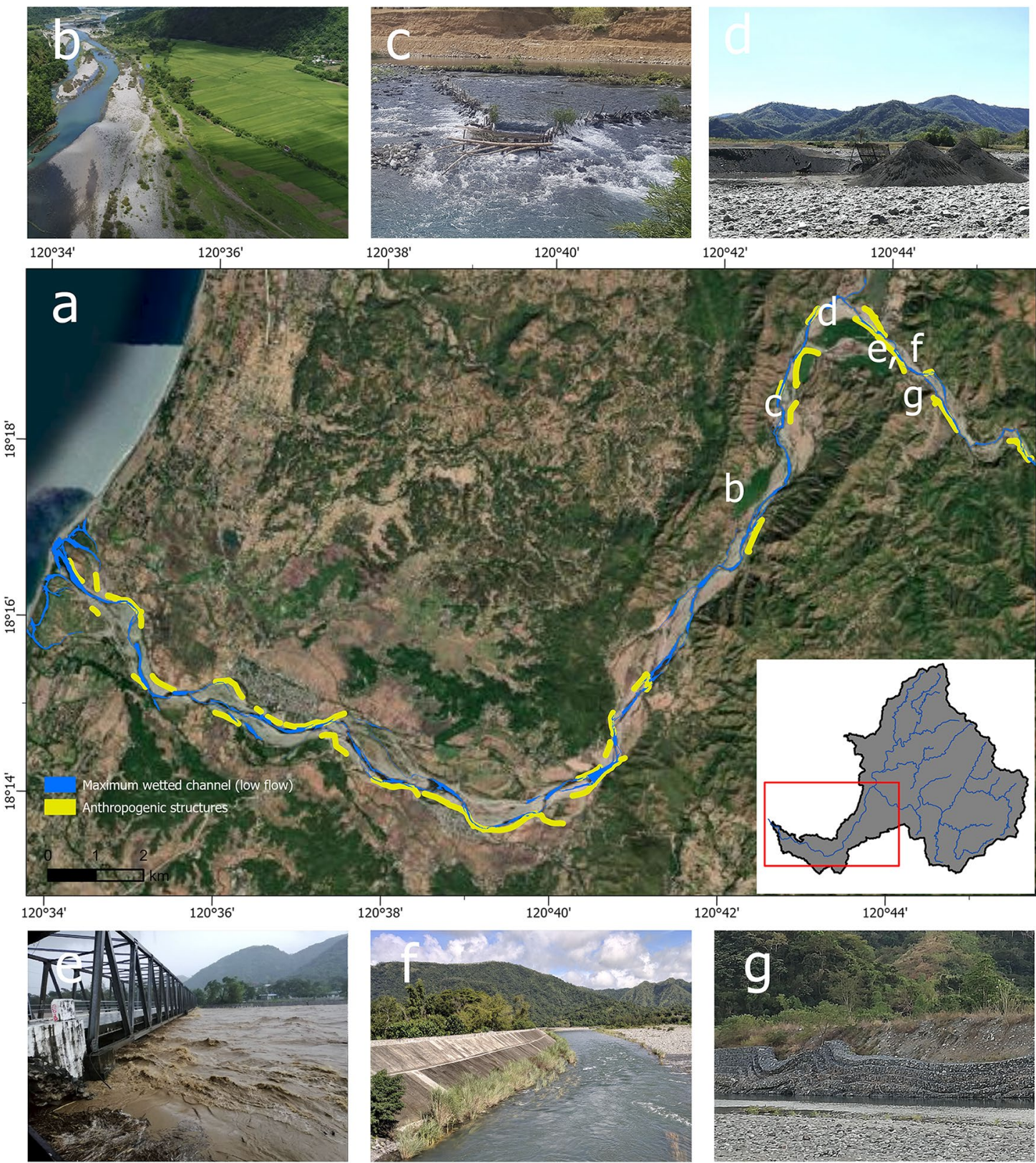

$120^{\circ} 42^{\prime}$

$120^{\circ} 44^{\prime}$
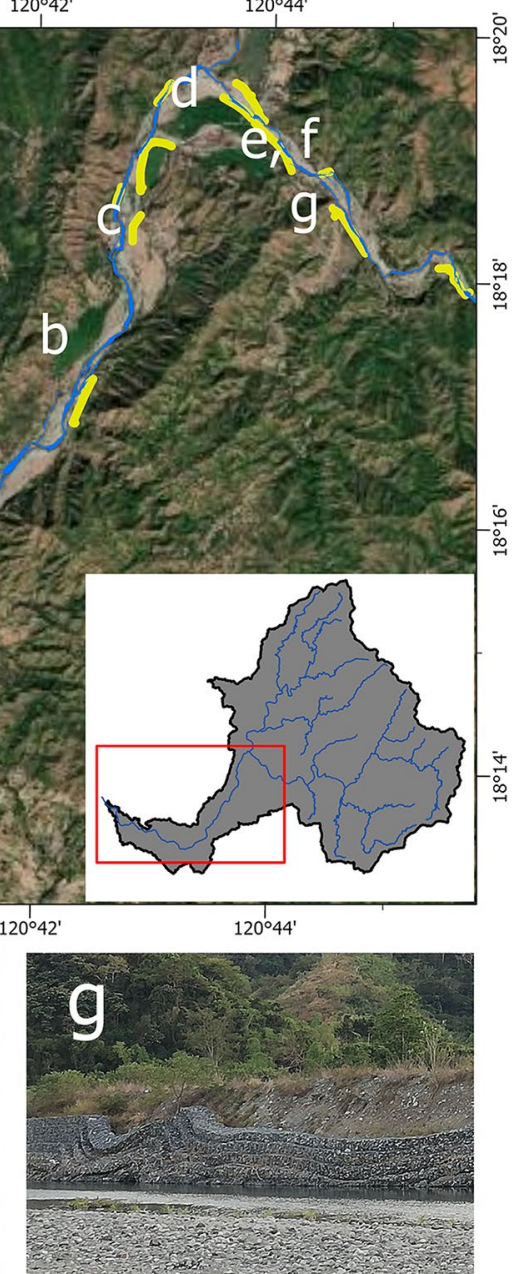

Fig. 1 a The Bislak River, like many rivers in the country, serves multiple purposes in Philippine communities, including: b agriculture on floodplains; c aquaculture/fish pens in channels; and, $\mathbf{d}$ the provision of construction materials from gravel mining on riverbeds and bars. Semi-permanent/ permanent structures such as bridges, embankments, dikes, and gabions $(\mathbf{e}-\mathbf{g})$ are commonly constructed along Philippine rivers. Examples shown are from the Bislak Catchment; locations are indicated by the corresponding labels $(\mathbf{a}-\mathbf{g})$

and maintain. Considering the increasing magnitude and variability of river flows and growing pressures on water supply from climate change and floodplain land use for agricultural and urban development (Tolentino et al. 2016; Eccles et al. 2019), such management responses could pose serious problems for the future.
Hence, geomorphologically informed approaches to river management in the Philippines are critical.

In this study, we use the River Styles Framework to appraise topographic controls on river morphological diversity and its subsequent implications on river management. First, we identify distinct River Styles through 
topographic analysis of a recent digital elevation model (DEM), interpretation of satellite and aerial imagery, and ground-truthing in the Bislak Catchment, Philippines. Then using stream power as a measure of the capacity of rivers to erode and transport sediment, we evaluate whether a simple stream power model can be used to predict patterns in River Styles. Based on the patterns of morphological river diversity in the Bislak Catchment, we recommend a range of transferrable, geomorphologically informed strategies that can contribute towards improved place-based understanding of river character and behaviour in the Philippines, essential for effective river management.

\section{Catchment and regional setting}

Bislak Catchment and Bislak River overview

The Bislak Catchment $\left(586 \mathrm{~km}^{2}\right)$ is located in the Ilocos Region, Luzon Island, Philippines (Fig. 2a). Its headwaters are bounded by the Luzon Central Cordillera (LCC)
Mountain Range with a maximum elevation of $1857 \mathrm{~m}$ (Fig. 2b). The catchment shares similar topographic characteristics with other small to medium-sized Philippine catchments with mountainous headwaters having steep terrain and high relief. The average catchment slope is $21.9^{\circ}$ (Fig. 2c) and 10\% of the catchment area is distributed above $1000 \mathrm{~m}$. The river network flows west and discharges into the South China Sea (average channel slope $=0.044 \mathrm{~m} / \mathrm{m}$ ).

The Bislak River is a valuable resource for the local community; as a water source for domestic and agricultural purposes, a habitat for freshwater species, an economic resource for aggregate (i.e., sand and gravel) extraction, a food source, and a recreational and cultural amenity through the annual River Ritual. Almost half of the population of the municipalities of Bacarra $(15,937)$ and Vintar $(15,753)$ reside on the Bislak River floodplains (Philippines Statistics Authority 2015), in locations highly susceptible to flooding (Paringit and Pascua

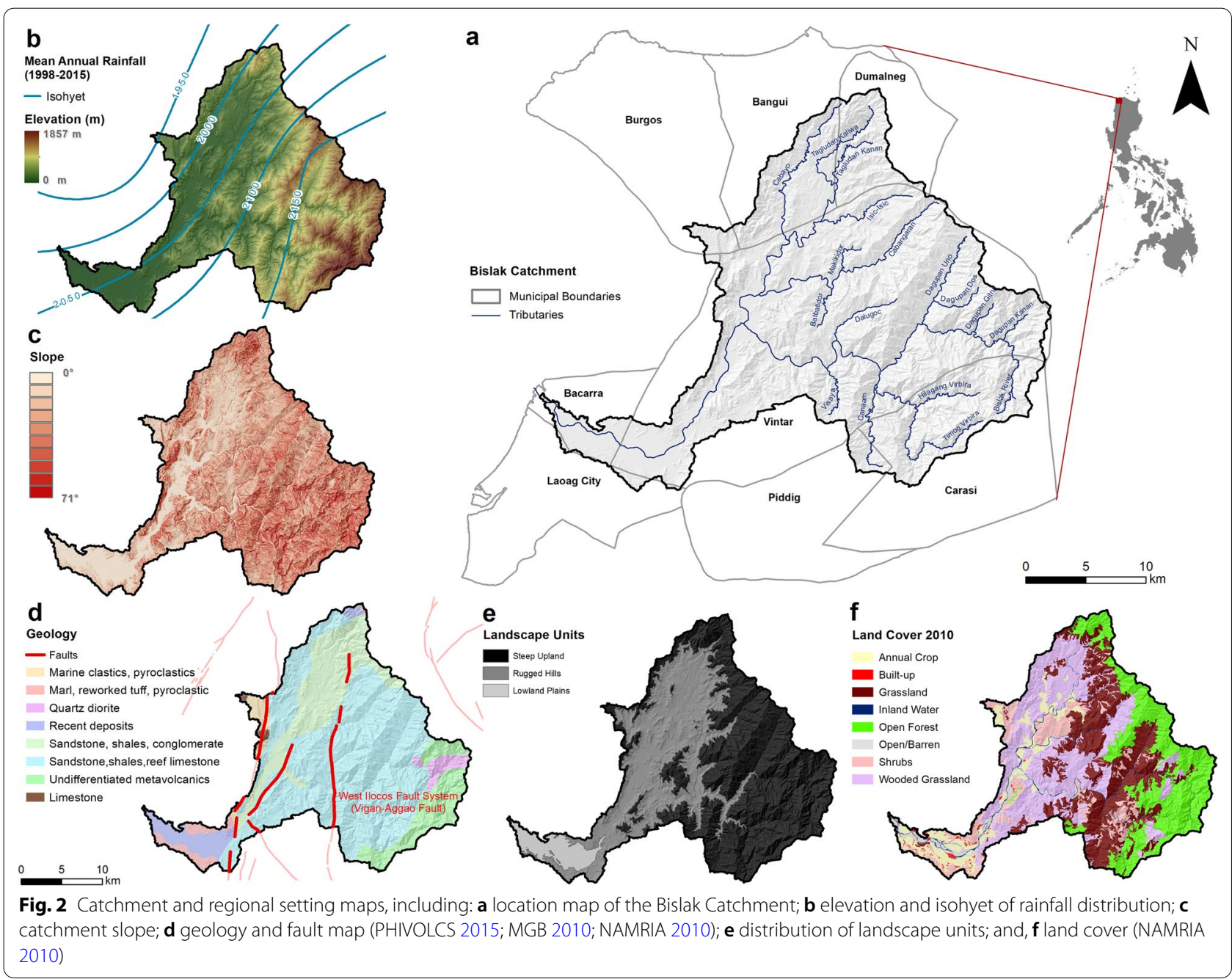


2017). In attempts to mitigate the flood and erosion hazards, hard engineering structures have been installed along the riverbanks (e.g., Fig. 1f), and the riverbed is frequently dredged to reduce the effects of aggradation and to increase channel conveyance. Similar hard engineering structures have been installed in other catchments where communities live adjacent to rivers (e.g., Talisay River; Paz-Alberto et al. 2017).

\section{Climate}

There are four climate types in the Philippines based on the distribution of rainfall. The Bislak Catchment has a Type I climate classified as having two distinct seasons, dry from November to April and wet from May to October (Coronas 1920). Annual rainfall totals are high (Fig. 2b) and are influenced by the Southwest Monsoon that advances from May to October, and the Northeast Monsoon from October to March. Mean annual rainfall (1969-2018) at the Laoag Synoptic Station (10.5 km southwest of Vintar) is $2019 \mathrm{~mm}$, with the maximum monthly mean being $546 \mathrm{~mm}$ in August. An increasing average monthly rainfall was observed in the region from 1969 to 2018 (PAGASA 2019). The International Best Track Archive for Climate Stewardship (IBTracs) shows that 83 tropical cyclones crossed within a $100 \mathrm{~km}$ radius of the Bislak Catchment from 1980 to 2019 (NOAA NCDC), most of these being from May to November. Recently, the Ilocos Region was placed under a state of calamity due to tropical cyclone impacts caused by Typhoon Ompong (Mangkhut; 2018) and Typhoon Ineng (Bailu; 2019).

\section{Geology}

Geology in the Bislak Catchment is heterogenous, with thick sequences of sedimentary rock units and local exposures of intrusive and volcanic igneous rocks (Fig. 2d). The headwaters of the catchment are underlain by conglomerates, breccias, sandstones, and intrusive rocks of the Bangui (Late Eocene-Late Oligocene) and Bojeador (Early Miocene) Formations. Less resistant sedimentary rocks belonging to the Pasuquin Limestone (Late Miocene) and Laoag (Late Early Pliocene-Pleistocene) Formation are exposed in the Rugged Hills (middle reaches), whilst recent alluvial deposits are generally found on the Lowland Plains. Northeast-trending lineaments are apparent along ridges in the headwaters and represent segments of the West Ilocos Fault System (WIFS) (i.e., Vigan-Aggao Fault) (Fig. 2d; Philippine Institute of Volcanology and Seismology 2015). The Vigan-Aggao Fault is an active oblique sinistral-strike-slip fault which has contributed to landscape deformation in northern Luzon (Rimando and Rimando 2020). The heterogenous geology and presence of active tectonic structures are important controls on the morphostructural characteristics of the Bislak Catchment.

\section{Landscape units and land cover}

We identified and mapped three morphostructural regions (landscape units) in the Bislak Catchment: Steep Uplands, Rugged Hills and Lowland Plains based on physiographic setting, landscape position, and relief (Fig. 2e). The landscape units represent portions of the catchment with similar morphostructural characteristics. Steep Uplands which comprise headwater areas account for $59 \%$ of the catchment area (mean elevation $705 \mathrm{~m}$ ). Rugged Hills, 36\% of the catchment (mean elevation $170 \mathrm{~m}$ ), are characterised by partly confined valleys ranging from 25 to $1300 \mathrm{~m}$ in width. Only $5 \%$ of the catchment area is classified as Lowland Plains (mean elevation $20 \mathrm{~m}$ ), where the river occupies an alluvial plain with continuous floodplain. These physical attributes impose boundary conditions that control the River Styles and their position in the Bislak Catchment.

Wooded grasslands and grasslands occupy approximately $30 \%\left(171.95 \mathrm{~km}^{2}\right)$ and $26 \%\left(153.09 \mathrm{~km}^{2}\right)$ of the total land area (Fig. 2f), respectively. Grasslands are dominant from the Steep Upland to Rugged Hills, while wooded grasslands only become dominant at the base of the Rugged Hills. Open forests occupy $23 \%$ of the catchment area $\left(137.74 \mathrm{~km}^{2}\right)$ and tend to be positioned at the eastern edge of the catchment in steep headwaters. Shrublands occupy approximately $10 \%\left(59.81 \mathrm{~km}^{2}\right)$ of the catchment area and tend to be positioned on valley bottoms. About $7 \%\left(43.67 \mathrm{~km}^{2}\right)$ of the catchment area is occupied by agricultural activities (including annual croplands) positioned along gentler hillslopes and relatively flatter floodplain areas adjacent to the inland water. Barren areas cover $2 \%\left(12.38 \mathrm{~km}^{2}\right)$ of the catchment area. Only a small fraction (0.5\%) of the catchment is classified as built-up, with scattered urban settlements throughout the rugged hill landscape and municipality centers at the Lowland Plains.

\section{Methods}

\section{Topographic analysis}

Topographic analysis used a nationwide digital elevation model (DEM) acquired in 2013 and generated through airborne IfSAR technology, with $5 \mathrm{~m}$ spatial resolution (1 $\mathrm{m}$ root-mean-square error vertical accuracy; Grafil and Castro 2014). TopoToolbox V2 was used to extract the stream network and calculate catchment areas using standard flow-routing algorithms (Schwanghart and Scherler 2014). An upstream area threshold value $\left(1 \mathrm{~km}^{2}\right)$ delineated the transition from debris flow-dominated channels to alluvial 
channels (Montgomery and Foufoula-Georgiou 1993); only alluvial channels $\left(>1 \mathrm{~km}^{2}\right)$ were considered for analysis. Non-parametric quantile regression was applied to remove data artefacts and errors in longitudinal profiles (i.e., hydrological correction). Quantile carving along the central tendency of the stream network elevation data $(\tau=0.5)$ ensured downstream decreasing elevations (Schwanghart and Scherler 2017). Because channel slope was variable over short distances, slope values were averaged over $0.2 \mathrm{~km}$ segment lengths $(n=1129)$. The mean elevation $[\mathrm{m}]$, mean slope $[\mathrm{m} / \mathrm{m}]$, and median catchment area $\left[\mathrm{km}^{2}\right]$ were extracted for each segment length and exported to a stream network shapefile. The position of the stream network was validated against recent Google Earth imagery. Thematic maps for land cover, geology and faults provided by the National Mapping and Resource Information Authority (NAMRIA), Mines and Geosciences Bureau (MGB), and Philippine Institute of Volcanology and Seismology (PHIVOLCS) were used in the analysis of the catchment and regional setting.

\section{River Style identification}

The procedural tree that underpins Stage One of the River Styles Framework was used to identify different river types across the Bislak Catchment (Brierley and Fryirs 2005; Fryirs and Brierley 2018). The naming convention followed Fryirs and Brierley (2018). Segments of the river with similar confinement (position of the channel on the valley bottom), channel planform (continuity, number of channels, sinuosity), geomorphic unit assemblage, and bed material texture were classified into discrete reaches termed River Styles (Brierley and Fryirs 2005; Khan and Fryirs 2020). Each River Style represents a spatial unit with distinctive hydromorphological attributes. Interpretation of Google Earth imagery, viewed at the reach $(\sim 1: 75,000$ to 1:10,000) and unit scales ( 1:5000 to 1:500) assisted River Style identification. Geomorphic attributes were ground-truthed and verified during field visits to accessible sites. The spatial distribution of River Styles was mapped and the longitudinal profiles for the major tributaries interpreted alongside boundaries from the catchment and regional setting analyses (e.g., Fig. 2b$\mathrm{f}$; including landscape units, valley settings, geology, contemporary process zones, and sediment transport regimes). The approach enabled the identification of controls on the position and type of river across the catchment (Rhoads 2020). Given the multitude of criteria being considered in the River Styles Framework, the classification ultimately depends on the expert judgement and decision of the researchers (Tadaki et al. 2014).

\section{Stream power}

Stream power is widely used as an indicator of the capacity of rivers to erode and transport sediment (Jain et al. 2006; Bizzi and Lerner 2015). Total stream power is calculated as:

$$
\Omega=\gamma Q S,
$$

where $\Omega\left[\mathrm{kg} \mathrm{m} \mathrm{s}^{-3}\right]$ is total stream power, $Q\left[\mathrm{~m}^{3} \mathrm{~s}^{-1}\right]$ is discharge and $S$ is reach slope. $\gamma$ is the unit weight of water $\left[\mathrm{kg} \mathrm{m}^{-2} \mathrm{~s}^{-2}\right]$ which is density $\left(1\left[\mathrm{~kg} \mathrm{~m}^{-3}\right]\right) \times$ gravity $\left(9.807\left[\mathrm{~m} \mathrm{~s}^{-2}\right]\right)$. $Q$ is a discharge that controls channel form, for which the bankfull discharge is often used (Petit et al. 2005). In landscape-scale studies, the relationship between catchment area, $A$, and $Q$ often uses a catchment area-discharge relationship derived for the region. Using data from 14 gauges in NW Luzon (Irrigation Division: Philippines 1924) collected in the early twentieth Century, the 2-year discharge $Q_{2}$ was estimated using the $\mathrm{R}$ package fasstr (https://github.com/bcgov/fasstr), and related to catchment area as $Q_{2}=0.44 A^{1.03}(n=14$; $R^{2}=0.93$; se $\left.=0.25\right)$ [Eq. 2]. The exponent is close to 1 (95\% confidence interval $0.85-1.20$ ), justifying substitution of $A$ for $Q_{2}$ in the stream power equation:

$$
\Omega=0.44 \gamma A S .
$$

For constant total stream power, catchment area and slope are thus inversely related, $A \alpha S^{-1}$. Thus, Eq. 2 can be solved for $0.2 \mathrm{~km}$ river segment lengths using the values for $A$ and $S$ derived from the topographic analysis (“Topographic analysis").

\section{Results \\ River diversity}

Eight River Styles were identified along $246 \mathrm{~km}$ of mapped stream length (Table 1 and Fig. 3). River Styles in a Confined valley setting, where $>85 \%$ of either channel margin abuts the valley bottom margin, account for $57.1 \%$ of the stream length. The confined reaches are located in upstream tributaries of the Steep Upland landscape unit (Fig. 2d), have a single-threaded, low sinuosity channel planform and bedrock or coarse bed material texture (boulder to cobble sized) with sculpted highenergy erosional geomorphic units. In confined reaches, there is limited capacity for the river to adjust laterally or vertically, except locally where isolated pockets of floodplain are present. River Styles in a partly confined valley setting, where $10-85 \%$ of either channel margin abuts the valley bottom margin, account for $36.5 \%$ of the stream length. These partly confined reaches are mainly located on moderate slopes of tributaries in the Rugged 


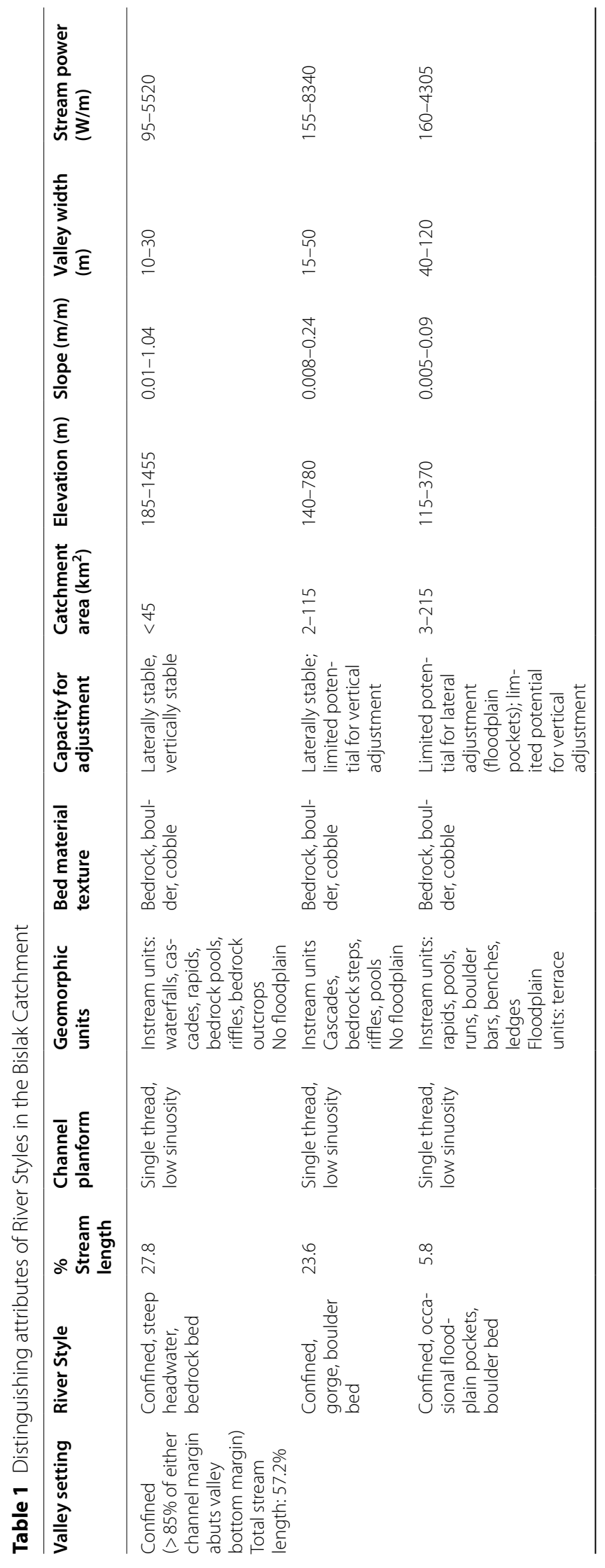




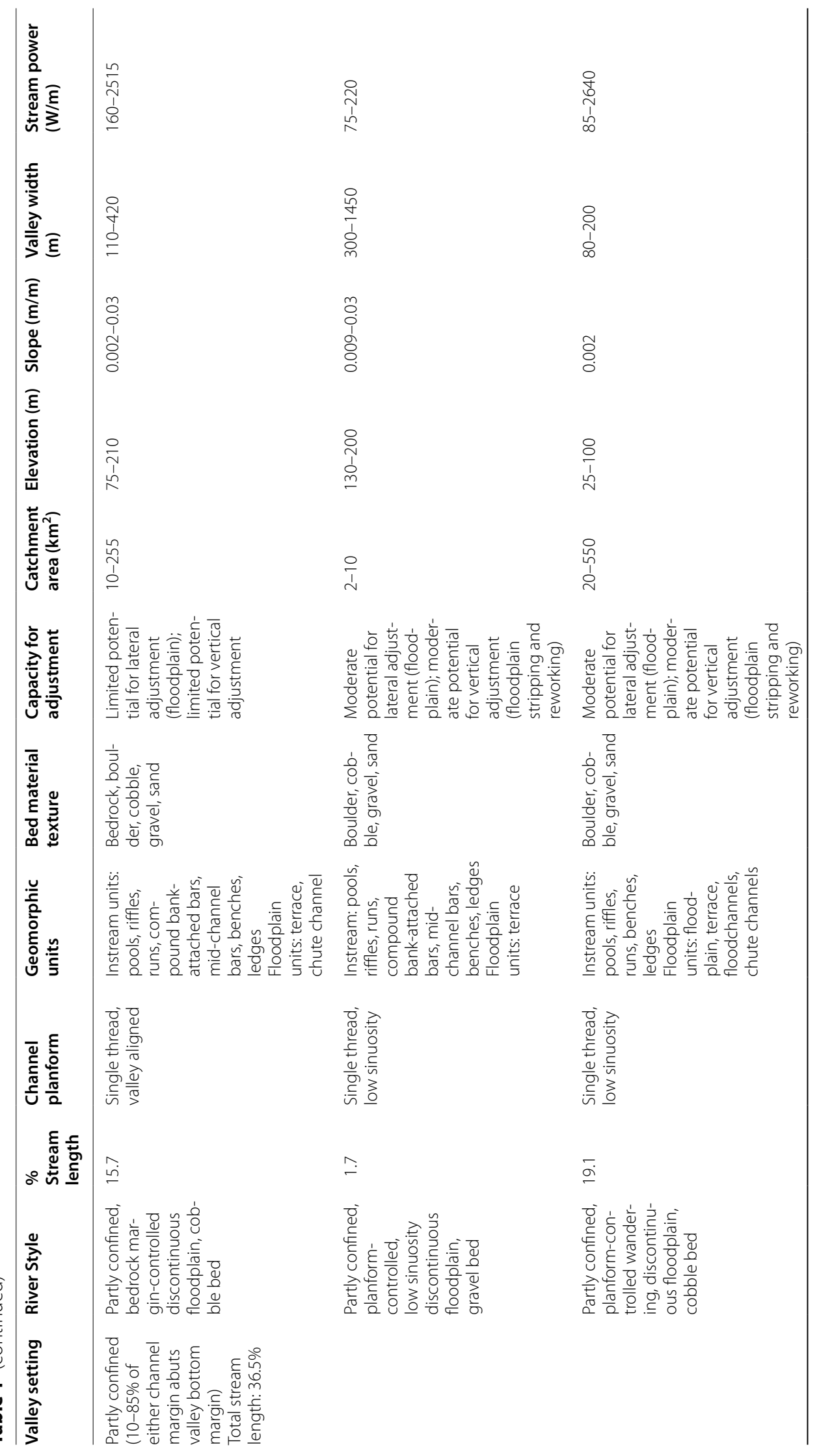




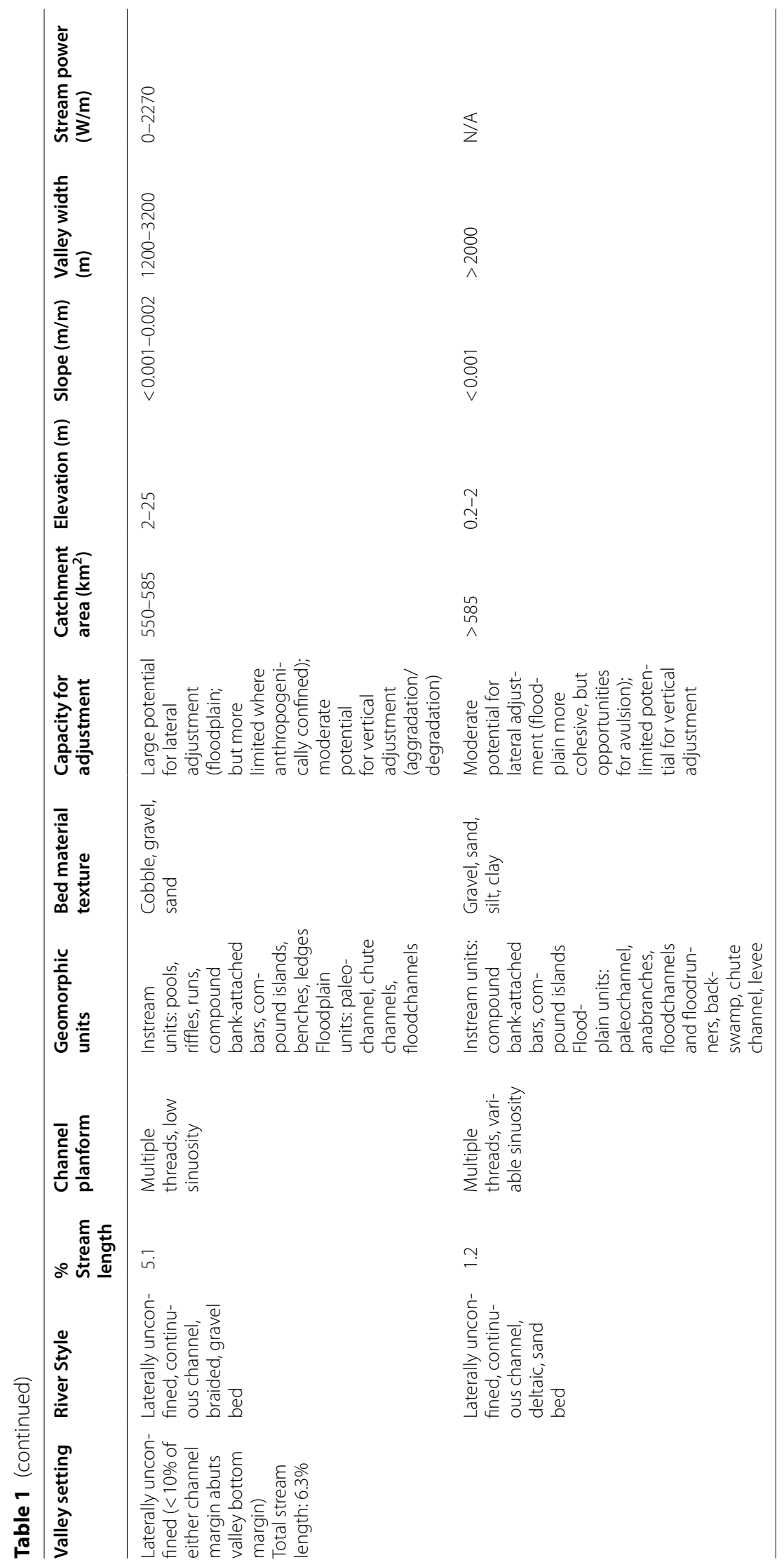




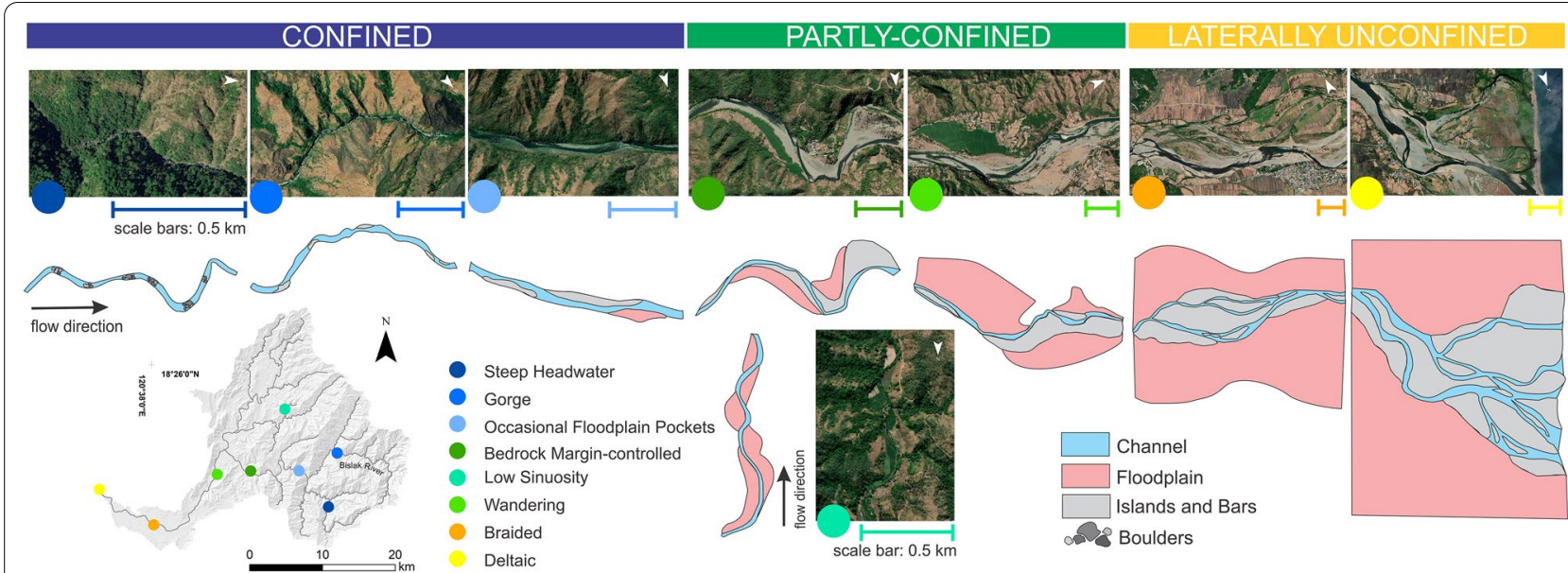

Fig. 3 River morphological diversity in the Bislak Catchment. Flow direction in the catchment is generally from east to west. Planform diagrams and aerial photos of the eight River Styles are arranged in a downstream sequence from left to right

Hills landscape unit, and have one to two channels and a mixed bed material texture (boulder to sand-sized). Mid-channel and bank-attached depositional units occur more frequently in these reaches than in confined reaches upstream. The capacity for adjustment is moderate, particularly where discontinuous floodplain pockets are present, meaning that floodplain stripping and reworking can occur (enabling both lateral and vertical adjustment; Nanson 1986). River Styles in a laterally unconfined valley setting account for only $6.3 \%$ of the stream length. These occur within the Lowland Plains landscape unit (Gob et al. 2016). The channel planform is predominantly multi-threaded with a mixed bed material texture (gravel to clay-sized). Geomorphic units in these reaches are products of short and long-term sediment accumulation such as compound islands and bars. Here, the capacity for lateral adjustment is greatest for these rivers, where the floodplain is continuous on both banks of the channel (Fig. 3). Several anthropogenic modifications (Fig. 1) designed to restrict lateral channel adjustment are present in the laterally unconfined river types.

\section{Downstream patterns in River Styles}

The distribution of downstream patterns (Fig. 4a) and processes along the river are presented by plotting the stream power against longitudinal profile-catchment area and annotating boundary conditions along the Bislak River (Fig. 5b). Note that stream power is spatially variable (Fig. 5b); calculated at $0.2 \mathrm{~km}$ intervals. The sources of all tributaries in the Bislak Catchment are in the Steep Upland landscape unit, and these tributaries flow through confined valleys (Fig. 4a and c) and wider partly confined valleys before joining the trunk stream (Bislak River). Five downstream patterns or sequences of River
Styles occur in the catchment (Fig. 4b). Pattern 1 is the dominant downstream pattern, exhibited by 11 out of 17 major tributaries (Figs. 4c and 5a) and is found where tributaries pass through areas with similar catchment controls (i.e., steep slopes with similar geology). In Pattern 1, the downstream sequence of River Styles is Steep Headwater, Gorge, and Occasional Floodplain Pockets found in the Confined valley setting; Bedrock Margincontrolled; Planform-controlled, Wandering, Discontinuous Floodplain found in partly confined valley setting; Continuous Channel, Braided; and finally, Continuous Channel, Deltaic found in the laterally unconfined valley setting. Two subsets arise from this pattern: Pattern 2 that passes through less resistant bedrock geology and does not contain Occasional Floodplain Pockets; and Pattern 3, a relatively short tributary that does not contain Gorges. Patterns 4 and 5 are only found in tributaries that initiate in the Steep Upland landscape unit but abruptly enter the Rugged Hills landscape unit as partly confined, Planform-controlled, Low Sinuosity, Discontinuous Floodplain. Pattern 4 exits to Bedrock Margincontrolled while Pattern 5 is set back in a Confined valley setting with Occasional Floodplain Pockets. The presence of active faults may partly explain the unique downstream patterns in River Styles, demonstrating the role of local factors affecting river character and behaviour.

\section{Differentiating river diversity with stream power}

There is a general inverse relationship between slope and catchment area (Fig. 5a). Different River Styles occupy different regions of the plot, with confined River Styles occurring on steeper slopes than partly confined River Styles. However, at any given catchment area, more than one River Style is encountered in both 


\section{a}
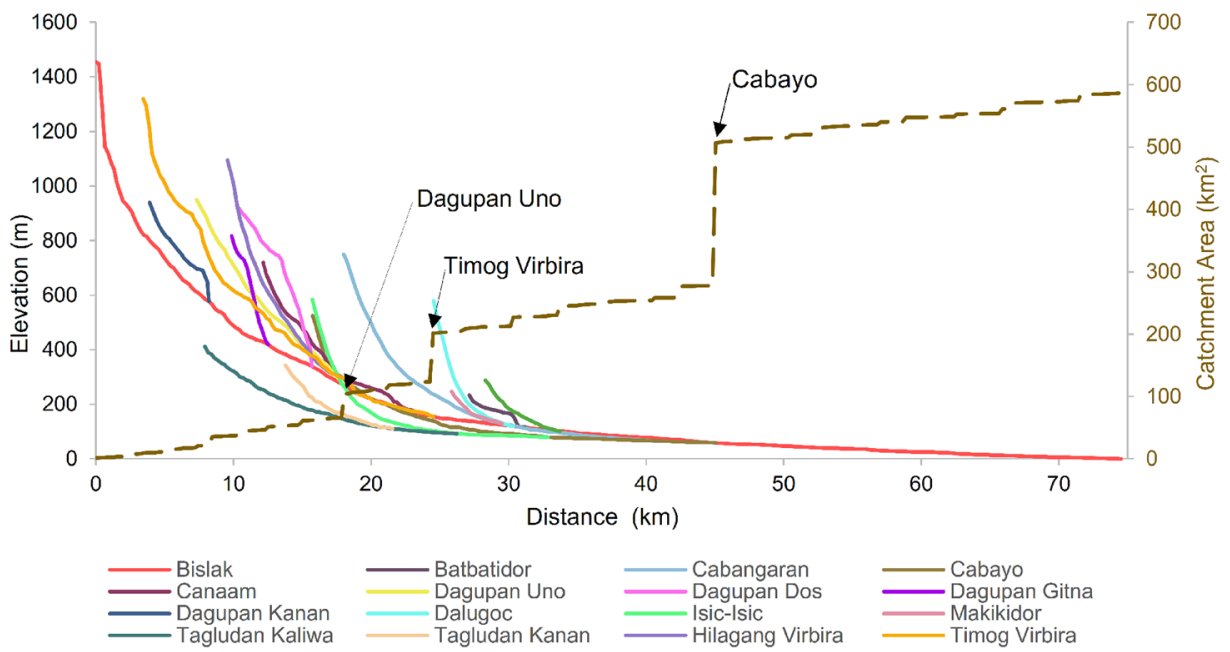

b

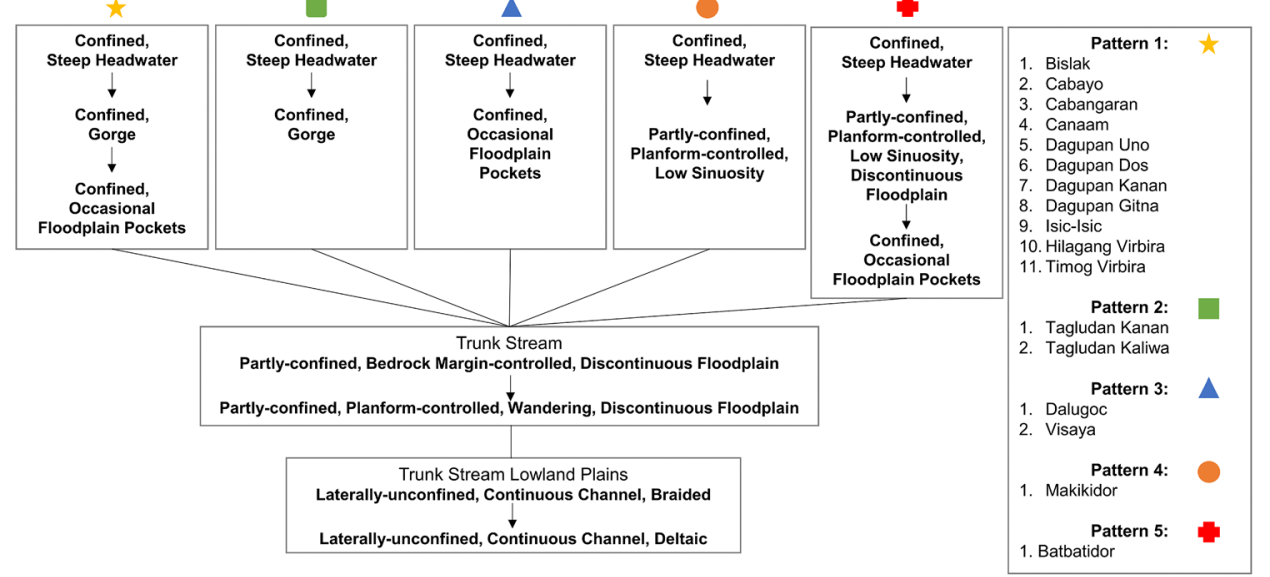

C

\section{Bislak Catchment River Styles}

Confined Valley Setting Steep Headwater

Gorge

Occasional Floodplain Pockets

Partly-confined Valley Setting Bedrock Margin-controlled

Planform-controlled, Wandering

Planform-controlled, Low Sinuosity

Laterally-unconfined Valley Setting

Continuous Channel, Braided

Continuous Channel, Deltaic

- River Styles Boundary

C Coastline SPoblacion of municipalities

Landscape Units Downstream Patterns

\begin{tabular}{|ll|}
\hline Steep Upland & Pattern 1: \\
\hline Rugged Hills & Pattern 2: \\
\hline Lowland Plains & Pattern 3: \\
& Pattern 4: \\
& Pattern 5:
\end{tabular}

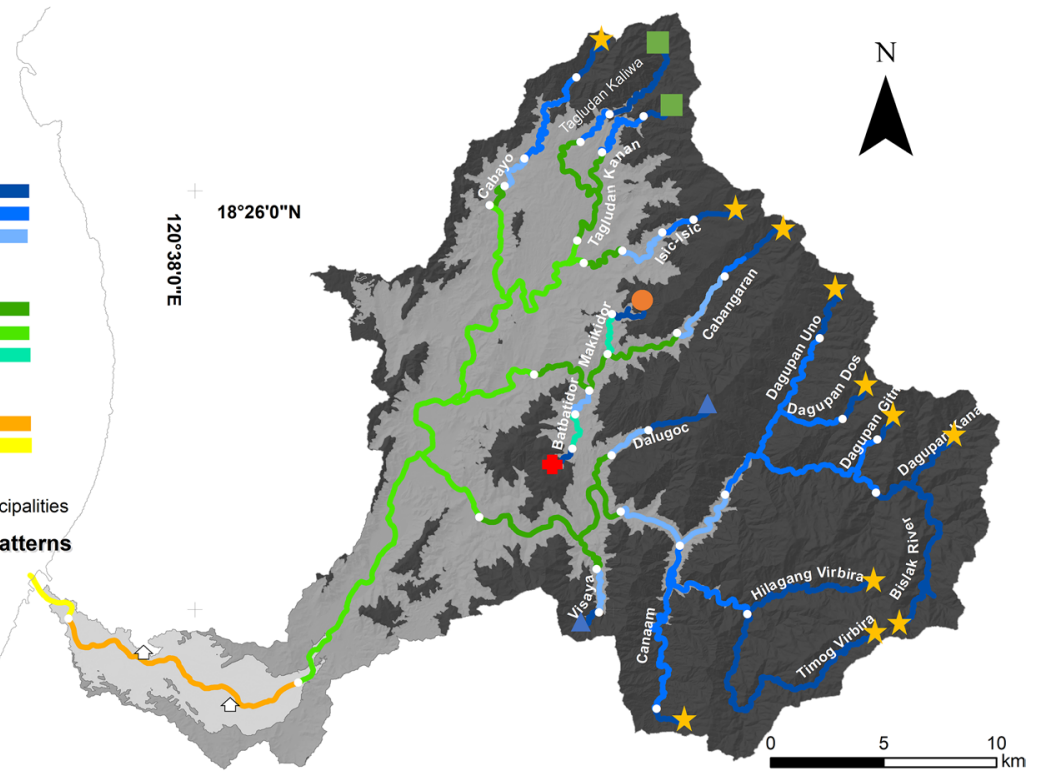

Fig. 4 Downstream patterns of River Styles in the Bislak Catchment. a Longitudinal profiles of the tributaries of the Bislak River. b Flow diagram of downstream patterns in the catchment and list of tributaries exhibiting each pattern. $\mathbf{c}$ Distribution of downstream patterns across the catchment 


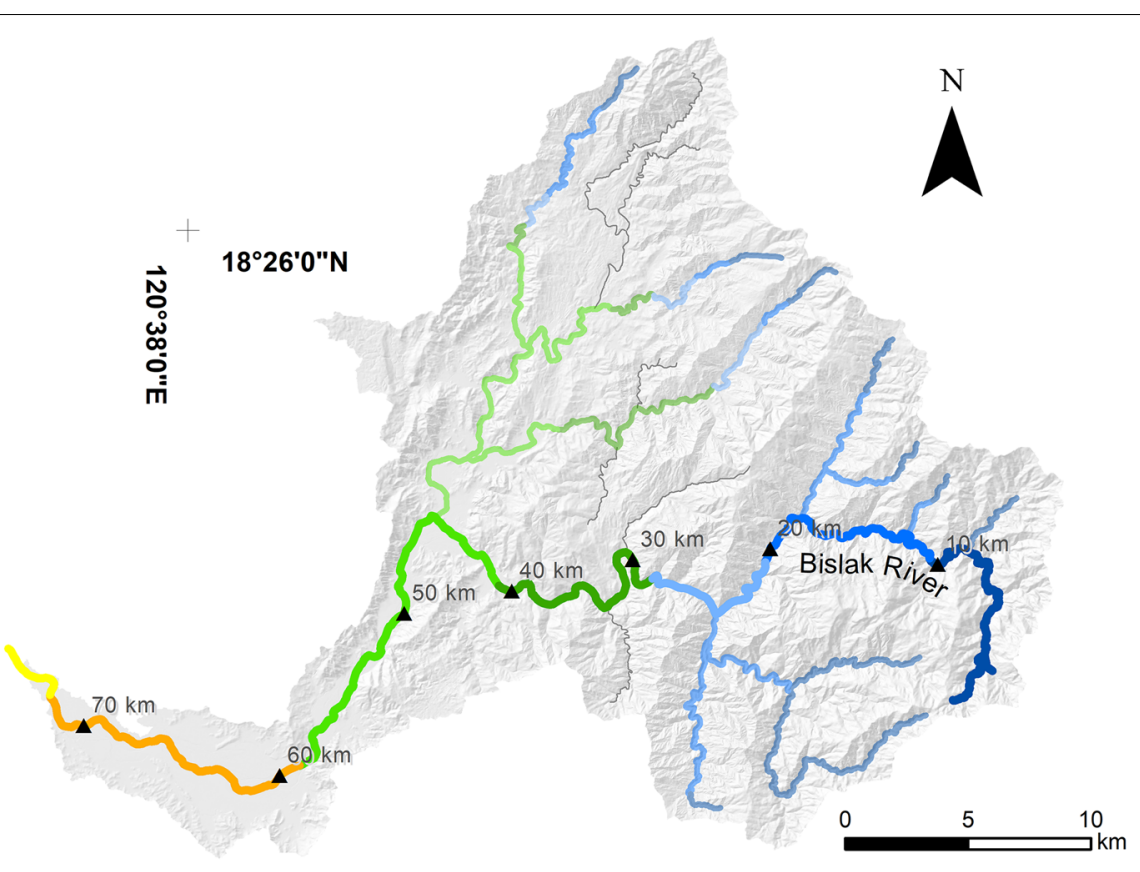

b
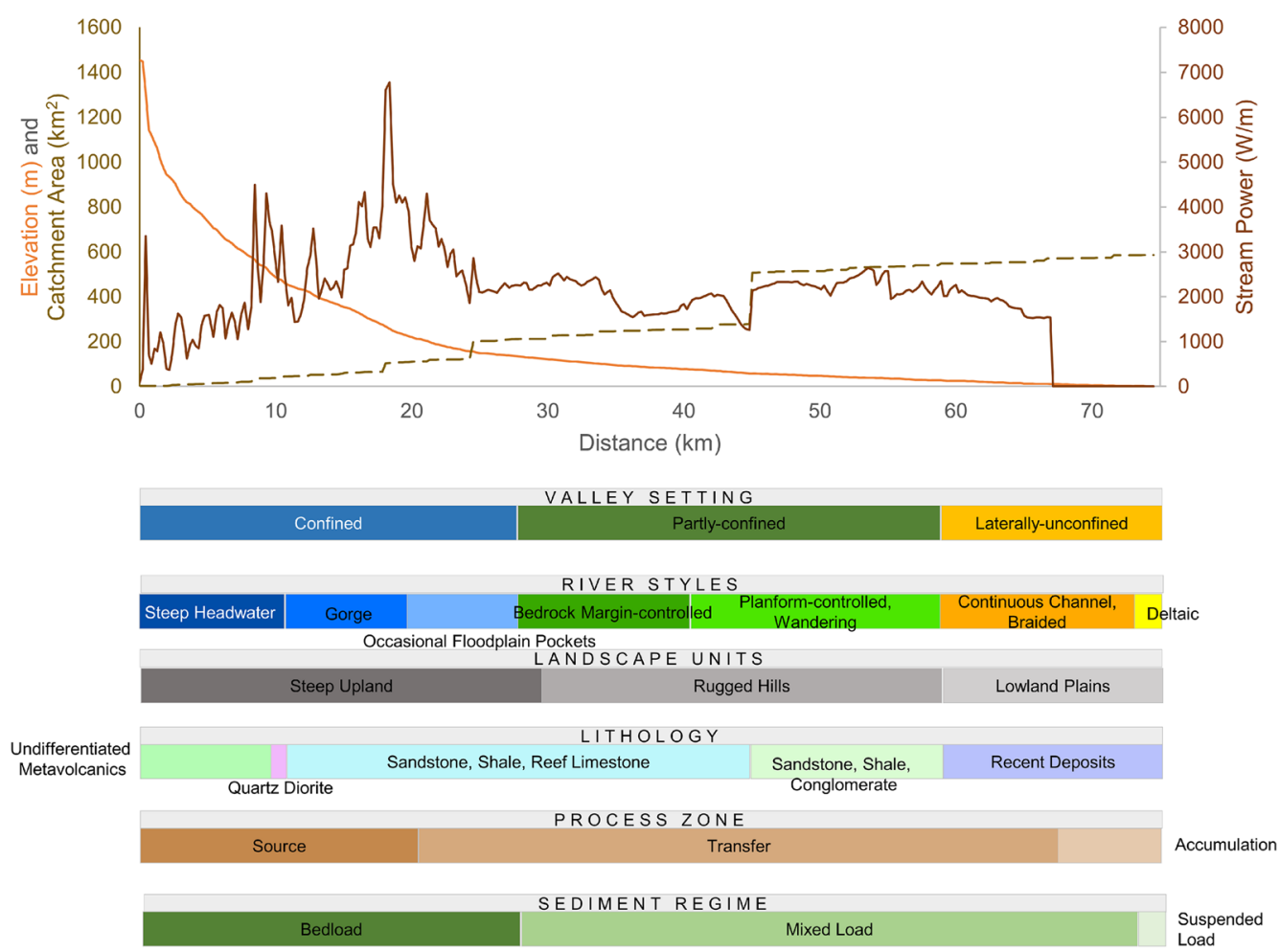

Fig. 5 a Distribution of Pattern 1 rivers in the Bislak Catchment. The trunk stream (Bislak River) is represented by thicker lines with markers to show the distance from the channel head to the outlet. Pattern 2-5 rivers are shown in grey. b Stream power against longitudinal profile-catchment area for the Bislak River (annotated with boundary conditions) 

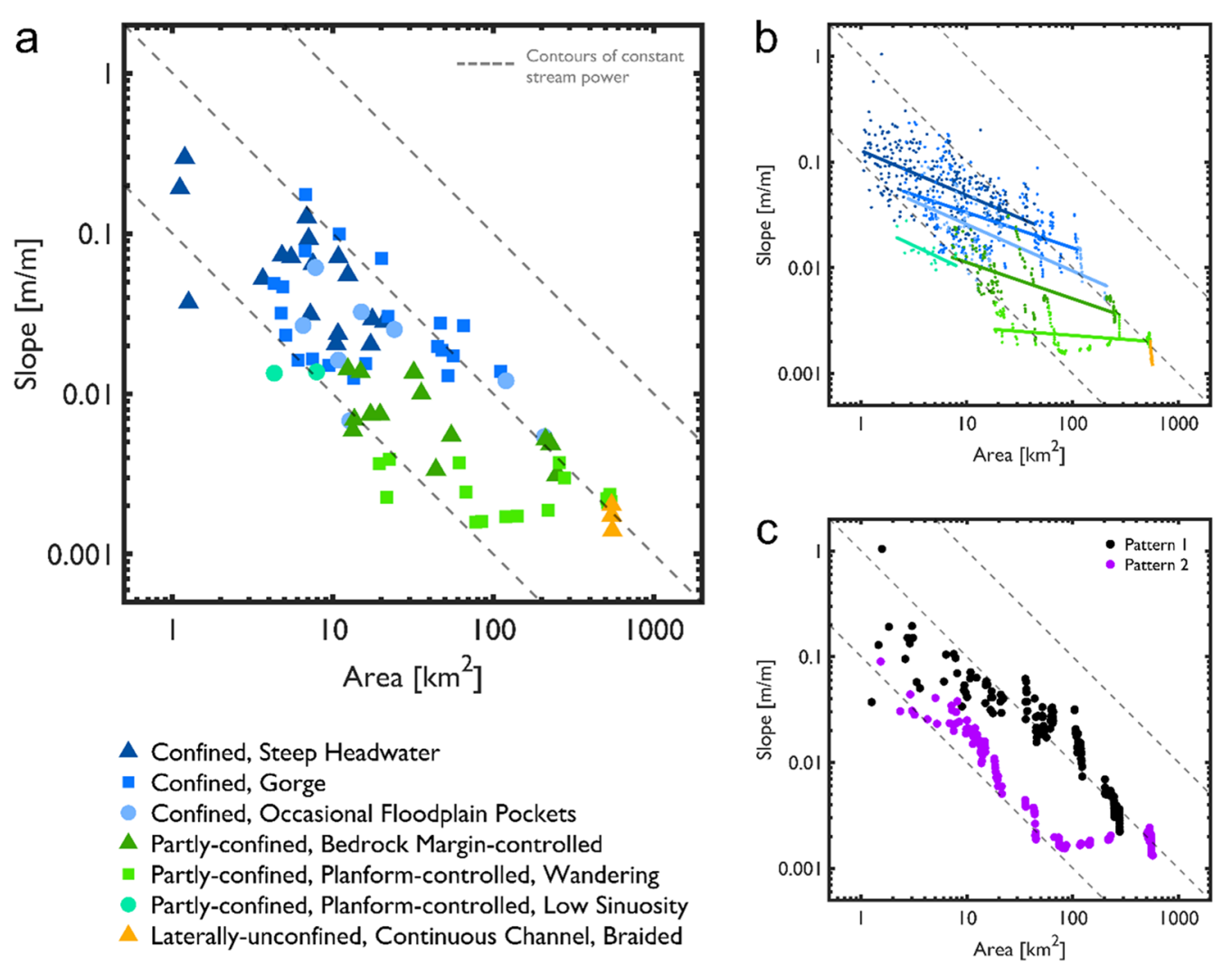

Fig. 6 Slope-catchment area relationships grouped by River Style: a values extracted at $2.5 \mathrm{~km}$ intervals along the stream network $(n=89) ; \mathbf{b}$ values averaged over $0.2 \mathrm{~km}$ segment lengths $(n=1129)$, coloured solid lines are log-log regressions; and, c comparisons between downstream Pattern 1 and Pattern 2. Dashed lines are contours of constant stream power $\left(S a Q^{-1}\right.$, see text for details)

confined and partly confined valley settings occurring at all catchment areas between 5 and $120 \mathrm{~km}^{2}$ (Fig. 6a). This overlap between River Styles becomes more apparent when all data are plotted (Fig. 6b). The regression lines in Fig. $6 \mathrm{~b}$ have gradients significantly less than the contours of constant stream power lines, and the gradient of all the data regression is -0.70 $[ \pm 0.03]$. The significance of stream power is further emphasised when considering the slope-area data for individual river patterns (Fig. 6c; see Fig. 4 for pattern definitions).

Overall, the slope-area relationships reflect the general shape of the topography (Fig. 6c) which also determines stream power. However, stream power is not the sole control over river morphology (Fig. 6a, b) suggesting that valley topography, stream network structure and hence lithology have significant influences on morphological diversity. Note that the gradient of the constant stream power lines will be steeper if river morphology is controlled by a less frequent flow than bankfull, as the gradient of relationships between discharge and area reduces as flow frequency decreases (Burgers et al. 2014).

\section{Discussion}

\section{River diversity and downstream patterns}

Stage One of the River Styles Framework revealed the diversity of fluvial morphology in the Bislak Catchment. The identified River Styles operate under a combination of imposed boundary conditions (including landscape units, lithology, and valley-setting) which influences process zone distributions, interplaying with flux boundary conditions that affect stream power (as a function of slope and contributing catchment area).

In the Bislak Catchment, confined River Styles are characterised by small drainage areas, and steepest slopes (Fig. 6a). Initiating with a Steep Headwater River Style (Fig. 5), a change in lithology from metavolcanics to sedimentary bedrock results in transition to a Gorge River Style. With increasing catchment area and the channel 
slope remaining high (in the range $0.008-0.24 \mathrm{~m} / \mathrm{m}$; Table 1), the stream power gradually increases to a peak of $8340 \mathrm{~W} / \mathrm{m}$ through the confined valley setting. Even though the stream power remains high (maximum $4305 \mathrm{~W} / \mathrm{m}$; Table 1), the storage potential is limited in Occasional Floodplain Pockets given the limited accommodation space in the valley bottom (Figs. 3 and $6 \mathrm{c}$ ). Upon entering the Rugged Hills landscape unit, the valley confinement transitions to partly confined and the channel slope is reduced (in the range $0.002-0.03 \mathrm{~m} / \mathrm{m}$; Table 1). With discontinuous floodplain, there is a switch to Bedrock Margin-controlled and Planform-controlled, Wandering, Discontinuous Floodplain River Styles. Stream power falls to a maximum of $2640 \mathrm{~W} / \mathrm{m}$ and remains approximately consistent (as increases in discharge from tributary inputs are offset by downstream reductions in slope). At the downstream end of the Lowland Plain landscape unit, the stream power is reduced to $<2270 \mathrm{~W} / \mathrm{m}$ because of the decrease in channel slope (in the range $<0.001-0.002 \mathrm{~m} / \mathrm{m}$; Table 1 ). Such catchment-based fluvial geomorphic understanding is essential for explaining local hydromorphological patterns and processes.

The relationship between slope and catchment area shows the potential to determine the downstream pattern of River Styles in the Bislak Catchment (Fig. 6). Stream power analysis indicates the general topographic controls on the distribution of River Styles within the catchment. However, the overlap (variation in slope) between River Styles for a given catchment area (e.g., between confined and partly confined River Styles, Fig. 6) suggests that stream power alone is insufficient to differentiate and predict river character. To fully appraise the morphological diversity, a hierarchical approach such as the River Styles Framework can complement topographic analyses to understand river character and behaviour. In the Bislak Catchment, patterns of River Styles reflect geologic controls upon valley setting alongside determinants of flow energy expressed as stream power, including analysis of discharge sediment supply, and vegetation controls (Buffington 2012).

Diversity in River Styles and their downstream patterns have been observed in other tropical river catchments. In the similarly sized $\left(616 \mathrm{~km}^{2}\right)$ but relatively steeper Liwu Basin in the eastern Central Range of Taiwan, confined River Styles dominate the channel network ( $82 \%$ of the stream length; Kuo and Brierley 2013). The downstream patterns of River Styles in the Liwu Basin are similar to those identified in the Bislak Catchment, with the transition from partly confined to laterally unconfined valley setting located towards the lower reaches of the catchment. The downstream patterns of River Styles along the Liwu River have been used as a guide to sediment storage; more than $95 \%$ of sediment storage occurred within the laterally unconfined valley setting (Kuo and Brierley 2013). Although comparable measurements of sediment storage have not been made for the Bislak Catchment, laterally unconfined valley settings represent a similarly small proportion of the total stream length between the catchments (6.3\% in the Bislak, $13 \%$ in the Liwu). Consequently, we might expect sediment storage to be limited to a disproportionately small portion of the Bislak Catchment. Fluctuating sediment supply from monsoon and typhoon related landslides, earthquakes, and volcanic eruptions are reported to be key geomorphic drivers in other Philippine catchments (Gran et al. 2011; Catane et al. 2012; Dingle et al. 2019).

In the relatively larger $\left(1800 \mathrm{~km}^{2}\right)$ Macaé Catchment in northern Rio de Janeiro State, Brazil, diversity in River Styles was most pronounced in the Mountain Escarpment landscape unit where there was variability in slope, valley confinement and valley sinuosity (Marcal et al. 2017). For the Bislak Catchment, six out of the eight identified River Styles were located in the Steep Upland and Rugged Hills landscape units, where the topography and geology were most variable (e.g., Table 1 and Fig. 2). Parallels between the lower reaches of the Macaé and Bislak Rivers can also be drawn. Lowland reaches of the Macaé River were channelized from the 1940s to 1980s for flood protection and the development of agricultural land, resulting in enhanced longitudinal connectivity (flow and sediment flux) and reduced lateral connectivity (Marcal et al. 2017). Due to these structural interventions, sections of the lower Macaé River have been irreversibly changed from a laterally unconfined, meandering sand bed River Style to a laterally unconfined, low sinuosity channelized River Style (Brierley et al. 2019). Anthropogenic structures (e.g., concrete dikes; Fig. 1d, f) along the laterally unconfined reaches of the Bislak River could modify patterns of longitudinal and lateral connectivity.

\section{Translation of River Styles principles to guide river management}

The River Styles Framework, contextualised using topographic and stream power analysis, showed the diversity of River Styles in the Bislak Catchment and the differences in their character and behaviour. Bespoke management strategies will be required to work with the local river character, behaviour, and capacity for adjustment. It is contended that the principles introduced in this paper are required to support sustainable river management across the Philippines. Table 2 outlines several key principles of the River Styles Framework (column 1) that are translated to a simplified understanding (column 2) and can support sustainable river management practices 
Table 2 River Styles principles that support the understanding of fluvial geomorphology and guide sustainable river management in the Bislak Catchment and more widely in the Philippines

\begin{tabular}{|c|c|c|}
\hline River Styles principles & Translated to a simplified understanding of: & $\begin{array}{l}\text { Implemented to guide river management } \\
\text { through: }\end{array}$ \\
\hline Capacity for adjustment & $\begin{array}{l}\text {-Whether the river can adjust laterally, vertically, } \\
\text { or both } \\
\text { - Where the river is likely to adjust, i.e. the spatial } \\
\text { distribution of bank erosion } \\
\text { - Where the river is confined and less able (or } \\
\text { unable) to adjust } \\
\text { - Where sediments will be deposited (aggrade) or } \\
\text { eroded (degrade) in the channel } \\
\text { - Whether the channel can shift (migrate, avulse) } \\
\text { and where this might occur }\end{array}$ & $\begin{array}{l}\text { - Land-use planning (e.g., where not to build infra- } \\
\text { structure or developments) } \\
\text { • Identification of hazardous buffer zones (flood- and } \\
\text { erosion-risk) } \\
\text { - Providing 'erodible corridors,'space to move', and/or } \\
\text { 'channel migration zones' guided by a working with } \\
\text { nature principle } \\
\text { - Strategic placement of necessary river control } \\
\text { structures }\end{array}$ \\
\hline River diversity & $\begin{array}{l}\text { - Recognizing the diverse types of river, with vari- } \\
\text { ous rates of adjustment, and behaviour } \\
\text { - Distinct characteristics and hydromorphological } \\
\text { attributes } \\
\text { - Whether the reach is sensitive or resilient }\end{array}$ & $\begin{array}{l}\text { - Which reaches (parts of the river) should be } \\
\text { prioritized for catchment action planning (e.g., for } \\
\text { conservation value), or to maintain sediment sources } \\
\text { to prevent downstream degradation } \\
\text { - Different types of reach require different types of } \\
\text { interventions }\end{array}$ \\
\hline Identifying geomorphic units & $\begin{array}{l}\text { - The presence of diverse geomorphic units signi- } \\
\text { fies the types of river styles } \\
\text { - Indicates how the river behaves } \\
\text { - Differentiates erosional or depositional features }\end{array}$ & $\begin{array}{l}\text { - Understanding where different habitats are located } \\
\text { (e.g., fishing) and recreational areas } \\
\text { - Areas for sustainable gravel extraction }\end{array}$ \\
\hline Pattern of rivers & $\begin{array}{l}\text { - Whether the pattern is unique or similar to other } \\
\text { patterns in the catchment } \\
\text { - Whether the boundaries between River Styles are } \\
\text { gradual or distinct (abrupt) }\end{array}$ & $\begin{array}{l}\text { - How sensitive different reaches are to pattern } \\
\text { transitions due to changes in water or sediment } \\
\text { supply, from upstream management decisions and } \\
\text { climate change impacts (i.e., connectivity and offsite } \\
\text { impacts) }\end{array}$ \\
\hline Position in catchment and controls & $\begin{array}{l}\text { - Whether the reach is a source zone, transfer zone } \\
\text { or accumulation zone } \\
\text { - Whether the reach is situated in a low, moderate, } \\
\text { or high energy environment } \\
\text { - Possible geologic and tectonic influences }\end{array}$ & $\begin{array}{l}\text { - Policies for extractive activities } \\
\text { - Identification of geomorphic hazards (e.g., land- } \\
\text { slides, debris flows) } \\
\text { - Floodplain zonation }\end{array}$ \\
\hline Tributary-trunk relationships (connectivity) & $\begin{array}{l}\text { - Relative fluxes of water and sediment discharge } \\
\text { from different parts of the catchment } \\
\text { - Downstream changes in grain size and thus } \\
\text { roughness and water depth during high flows }\end{array}$ & - Land-use planning in vicinity of confluences \\
\hline Know your catchment & $\begin{array}{l}\text { - Regional settings and location influences the dif- } \\
\text { ferences between catchments }\end{array}$ & $\begin{array}{l}\text { - Locally appropriated management options, includ- } \\
\text { ing socio-economic considerations and indigenous } \\
\text { practices }\end{array}$ \\
\hline Nested hierarchical approach & $\begin{array}{l}\text { - Range of analyses and approaches that can be } \\
\text { undertaken in different scales. Top-down approach } \\
\text { on controls on character and behaviour while } \\
\text { bottom-up approach on interpretation of the } \\
\text { character and behaviour }\end{array}$ & $\begin{array}{l}\text { - Coordination of management approaches from dif- } \\
\text { ferent local and national government agencies }\end{array}$ \\
\hline
\end{tabular}

(column 3). Indeed, we argue that effective river management cannot be reliably conducted independent from geomorphic insights into catchment-scale patterns of river character and behaviour.

The Bislak River serves a range of functions for the community (Fig. 1b-c). Neglecting the principles of fluvial geomorphology can lead to reactive management, exemplified by expensive and unsustainable attempts to control the river in addressing hydrometeorological risks (Fig. 1g). In the Bislak Catchment, river management has currently involved construction of multiple structures including flood defences, embankments, gabion walls, and flow deflectors (Fig. 1e-g). The structures are frequently damaged and require regular repair following high-magnitude flows. The effects of the structures on the geomorphology of the river are often left unaccounted for but may negatively affect flow patterns and sediment flux (Brierley et al. 2011). Disregarding the principles of fluvial geomorphology often leads to mismanagement of a river, posing threats to the ecosystem the river is supporting (Brierley 2008).

Translating the principles of Stage One of the River Styles Framework to the management of the Bislak Catchment (and Philippine rivers more widely) revealed 
the diversity of River Styles in one small catchment. Although physical processes and principles which control the river form are universal, the context of the river, particularly catchment properties and anthropogenic history mean that the outcomes of these principles will not always be the same and recognising and understanding such differences are critical for effective management (Brierley et al. 2011). The new insights provided by the River Styles Framework (as we demonstrate in this study) can be used to develop pro-active and effective strategies for managing river systems that works with the river. These principles provide an entry point for hydromorphological information to be incorporated into river basin management and catchment action plans. Subsequent stages of the River Styles Framework, focusing on river evolution and the assessment of geomorphic condition as a basis to predict future trajectories and recovery potential (Fryirs and Brierley 2016; Brierley and Fryirs 2016). Such insights can be used to inform policies for various river projects including but not limited to sustainable river gravel quarrying plans, upstream intervention for flood mitigation, and river use management.

Lastly, since the River Styles Framework is an involved process and relies on interpretation (i.e., field-assessment, interpreting imagery, etc.), assessment of river character and behaviour over large areas will continue to remain a challenge. That said, the predictions based on topographic and stream power analyses that we demonstrate here could potentially contribute to further studies that automate and upscale these analyses for larger scale roll-out (e.g., Fryirs et al. 2019; Boothroyd et al. 2021a; Khan et al. 2021).

\section{Conclusions}

This study utilises the River Styles Framework to show that sustainable river management should account for geomorphic insight into both the character and behaviour of rivers. In the Bislak catchment $\left(586 \mathrm{~km}^{2}\right)$, we identified eight distinct River Styles with Confined (57\%) and Partly confined (37\%) River Styles dominating the stream network by length. Five downstream patterns influenced by imposed and flux boundary conditions exist in the catchment. These findings indicate that a representative Philippine catchment such as Bislak (ranked 55 in the Philippines by catchment area) exhibits different River Styles and downstream patterns requiring different management strategies. Furthermore, variation in channel slope for a given catchment area (i.e., total stream power) is shown to be insufficient to differentiate the type of river in a given reach, hence the need to understand the differences between channel reaches beyond such metrics. The guiding principles of the River Styles Framework of reading the landscape, working with nature, and knowing your catchment by respecting the diversity and the different patterns of rivers at the catchment scale (Brierley and Fryirs 2005) are starting points for developing catchment-scale visions and moving towards geomorphologically informed, sustainable river management.

\section{Acknowledgements}

This research was undertaken as part of a Natural Environment Research Council (NERC) — Department of Science and Technology_Philippine Council for Industry, Energy and Emerging Technology Research and Development (DOST-PCIEERD) - NERC Newton Fund grant (NE/S003312/1) and Global Challenges Research Fund (SFC-GCRF) grant. Pamela Tolentino acknowledges DOST-Science Education Institute (DOST-SEI) and British Council for her Ph.D. Scholarship. Gary Brierley (University of Auckland) and Kirstie Fryirs (Macquarie University) acknowledge support from their host universities in the conduct of this work.

\section{Authors' contributions}

Conceptualization: PT, RB, TH, RW, KF, and GB. Methodology: PT, JP, EG, RB, TH, RW, KF, and GB. Software: PT, JP, EG, RB, and TH. Formal analysis: RB and TH. Investigation: $P T, J P, E G, R B$, and TH. Resources: KF and GB. Writing-original draft: PT, JP, EG, RB, and TH. Writing - review and editing: RW, KF, GB, and CD. Visualization: PT and RB. Supervision: RW and CD. Project administration: PT, RW, and CD. Funding acquisition: PT, RW, and GB. All authors read and approved the final manuscript.

\section{Funding}

Department of Science and Technology_Philippine Council for Industry, Energy and Emerging Technology Research and Development (DOSTPCIEERD)—NERC Newton Fund grant (NE/S003312). Global Challenges Research Fund (SFC-GCRF) grant (2019).

Availability of data and materials

Following review, all GIS datasets will be made available through the NERC data repository.

\section{Declarations}

\section{Competing interests}

The authors declare that they have no competing interests.

\section{Author details}

${ }^{1}$ University of the Philippines-Diliman, Quezon City, Philippines. ${ }^{2}$ University of Glasgow, Glasgow, UK. ${ }^{3}$ University of Vienna, Vienna, Austria. ${ }^{4}$ Brunel University London, London, UK. ${ }^{5}$ Macquarie University, Sydney, Australia. ${ }^{6}$ University of Auckland, Auckland, New Zealand.

Received: 4 August 2021 Accepted: 2 January 2022

Published online: 02 February 2022

\section{References}

Beechie TJ, Sear DA, Olden JD, Pess GR, Buffington JM, Moir H, Roni P, Pollock MM (2010) Process-based principles for restoring river ecosystems. Bioscience 60:209-222

Belletti B, Rinaldi M, Bussettini M, Comiti F, Gurnell AM, Mao L, Nardi L, Vezza P (2017) Characterising physical habitats and fluvial hydromorphology: a new system for the survey and classification of river geomorphic units. Geomorphology 283:143-157. https://doi.org/10.1016/j.geomorph.2017. 01.032

Bizzi S, Lerner DN (2015) The use of stream power as an indicator of channel sensitivity to erosion and deposition processes. River Res Appl 31:16-27. https://doi.org/10.1002/rra.2717

Boothroyd RJ, Williams RD, Hoey TB, Barrett B, Prasojo OA (2021a) Applications of Google Earth Engine in fluvial geomorphology for detecting river channel change. Wiley Interdiscip Rev Water 8(1):e21496. https://doi.org/ 10.1002/wat2.1496 
Boothroyd RJ, Williams RD, Hoey TB, Tolentino PL, Yang X (2021b) Nationalscale assessment of decadal river migration at critical bridge infrastructure in the Philippines. Sci Total Environ 768:144460. https://doi.org/10. 1016/j.scitotenv.2020.144460

Brierley GJ (2008) Geomorphology and river management. Kemanus Asian J Humanit 15:13-26

Brierley GJ, Fryirs KA (2005) Geomorphology and river management: applications of the river styles framework. Blackwell, Malden

Brierley GJ, Fryirs KA (2009) Don't fight the site: three geomorphic considerations in catchment-scale river rehabilitation planning. Environ Manag 43:1201-1218. https://doi.org/10.1007/s00267-008-9266-4

Brierley GJ, Fryirs KA (2016) The use of evolutionary trajectories to guide 'Moving Targets' in the management of river futures. River Res Appl 32(5):823-835. https://doi.org/10.1002/rra.2930

Brierley GJ, Fryirs KA, Cook N, Outhet D, Raine A, Parsons L, Healey M (2011) Geomorphology in action: linking policy with on-the-ground actions through applications of the River Styles framework. Appl Geogr 31(3):1132-1143. https://doi.org/10.1016/j.apgeog.2011.03.002

Brierley GJ, Fryirs KA, dos Santos Marçal M, Lima R (2019) The use of the River Styles framework as a tool to 'work with nature' in managing rivers in Brazil: examples from the Macaé catchment. J Rev Bras Geomorfol. https:// doi.org/10.20502/rbg.v20i4.1559

Buffington JM (2012) Changes in channel morphology over human time scales. In: Church M, Biron PM, Roy AG (eds) Gravel-bed rivers: processes, tools, environments, vol 32. Wiley, Chichester, pp 435-463. https://doi. org/10.1002/9781119952497

Buffington JM, Montgomery DR (2013) Geomorphic classification of rivers. In: Shroder J, Wohl E (eds) Treatise on geomorphology, vol 9. Elsevier, Amsterdam, pp 730-767. https://doi.org/10.1016/B978-0-12-374739-6. 00263-3

Burgers HE, Schipper AM, Hendriks AJ (2014) Size relationships of water discharge in rivers: scaling of discharge with catchment area, main-stem length and precipitation. Hydrol Process 28:5769-5775. https://doi.org/ 10.1002/hyp.10087

Catane SG, Abon CC, Saturay RM, Mendoza EPP, Futalan KM (2012) Landslideamplified flash floods-The June 2008 Panay Island flooding Philippines. Geomorphology 169-170:55-63. https://doi.org/10.1016/j.geomorph. 2012.04.008

Coronas J (1920) The climate and weather of the Philippines 1903-1918 Bureau of Printing, Philippines

Dallaire CO, Lehner B, Sayre R, Thieme M (2019) A multidisciplinary framework to derive global river reach classifications at high spatial resolution. Environ Res Lett 14(2):024003. https://doi.org/10.1088/1748-9326/aad8e9

Department of Environment and Natural Resources - Environment Management Bureau (DENR-EMB) (2016) Water quality guidelines and general effluent standards. https://pab.emb.gov.ph/wp-content/uploads/2017/ 07/DAO-2016-08-WQG-and-GES.pdf. Accessed 20 June 2020

Dingle EH, Paringit EC, Tolentino PLM, Williams RD, Hoey TB, Barrett B, Long H, Smiley C, Stott E (2019) Decadal-scale morphological adjustment of a lowland tropical river. Geomorphology 333:30-42. https://doi.org/10. 1016/j.geomorph.2019.01.022

Dollar ESJ, James CS, Rogers KH, Thoms MC (2007) A framework for interdisciplinary understanding of rivers as ecosystems. Geomorphology 89(1-2):147-162. https://doi.org/10.1016/j.geomorph.2006.07.022

Downs P, Gregory K (2004) River channel management; towards sustainable catchment hydrosystems, London, UK. Hodder Arnold, p 395

Eccles R, Zhang H, Hamilton D (2019) A review of the effects of climate change on riverine flooding in subtropical and tropical regions. J Water Clim Change 10(4):687-707. https://doi.org/10.2166/wcc.2019.175

Frissell CA, Liss WJ, Warren CE, Hurley MD (1986) A hierarchical framework for stream habitat classification: viewing streams in a watershed context. Environ Manag 10:199-214. https://doi.org/10.1007/BF01867358

Fryirs KA, Brierley GJ (2016) Assessing the geomorphic recovery potential of rivers: forecasting future trajectories of adjustment for use in management. Wiley Interdiscip Rev Water 3(5):727-748

Fryirs K, Brierley G (2018) What's in a name? A naming convention for geomorphic river types using the River Styles framework. PLoS ONE 13(9):e0201909. https://doi.org/10.1371/journal.pone.0201909

Fryirs K, Brierley G (2021) Applications and impact. https://riverstyles.com/ applications-and-impact/. Accessed 30 June 2021.
Fryirs KA, Wheaton JM, Bizzi S, Williams R (2019) To plug-in or not to plug-in? Geomorphic analysis of rivers using the River Styles Framework in an era of big data acquisition and automation. Wiley Interdiscip Rev Water 6(5):e1372. https://doi.org/10.1002/wat2.1372

Fuller I, Reid H, Brierley G (2013) Methods in geomorphology: investigating river channel form. In: Shroder J, Switzer AD, Kennedy DM (eds) Treatise on geomorphology, vol 14. Elsevier, Amsterdam, pp 73-91. https://doi. org/10.1016/B978-0-12-374739-6.00374-2

Gilvear DJ (1999) Fluvial geomorphology and river engineering: future roles utilizing a fluvial hydrosystems framework. Geomorphology 31:229-245

Gob F, Gautier E, Virmoux C, Grancher D, Tamisier V, Primanda KW, Wibowo SB, Sarrazin C, de Belizal E, Ville A, Lavigne F (2016) River responses to the 2010 major eruption of theMerapi volcano, central Java, Indonesia. Geomorphology 273:244-257

Grafil L, Castro O (2014) Acquisition of IfSAR for the production of nationwide DEM and ORI for the Philippines under the unified mapping project. Infomapper 21(12-13):40-43

Gran KB, Montgomery DR, Halbur JC (2011) Long-term elevated post-eruption sedimentation at Mount Pinatubo, Philippines. Geology 39(4):367-370

Gurnell AM, Rinaldi M, Belletti B, Bizzi S, Blamauer B, Braca G, Buijse AD, Bussettini M, Camenen B, Comiti F, Demarchi L, García de Jalón D, González del Tánago M, Grabowski RC, Gunn DM, Habersack H, Hendriks D, Henshaw AJ, Klösch M, Lastoria B, Latapie A, Marcinkowski P, Martínez-Fernández V, Mosselman E, Mountford JO, Nardi L, Okruszko T, O'Hare MT, Palma M, Percopo C, Surian N, van de Bund W, Weissteiner C, Ziliani L (2015) A multi-scale hierarchical framework for developing understanding of river behaviour to support river management. Aquat Sci Res Across Bound 78:1-16. https://doi.org/10.1007/s00027-015-0424-5

Hawley RJ (2018) Making stream restoration more sustainable: a geomorphically, ecologically, and socioeconomically principled approach to bridge the practice with the science. Bioscience 68(7):517-528

Hohensinner S, Hauer C, Muhar S (2018) River morphology, channelization, and habitat restoration. In: Schmutz S, Sendzimir J (eds) Riverine ecosystem management, vol 8. Aquatic ecology series. Springer, Cham. https:// doi.org/10.1007/978-3-319-73250-3_3

Irrigation Division: Philippines (1924) Surface water supply of the Philippine Islands 1908-1922: volume I-IV, Division of Irrigation: Bureau of Public Works. Manila: Bureau of Printing

Jain V, Preston N, Fryirs KA, Brierley GJ (2006) Comparative assessment of three approaches for deriving stream power plots along long profiles in the upper Hunter River catchment, New South Wales, Australia. Geomorphology 74:297-317. https://doi.org/10.1016/j.geomorph.2005.08.012

Kasprak A, Hough-Snee N, Beechie T (2016) The blurred line between form and process: a comparison of stream channel classification frameworks. PLoS ONE 11(3):e0150293. https://doi.org/10.1371/journal.pone.0150293

Khan S, Fryirs KA (2020) Application of globally available, coarse-resolution digital elevation models for delineating valley bottom segments of varying length across a catchment. Earth Surf Process Landf 45(12):2788-2803

Khan S, Fryirs KA, Ralph TJ (2021) Geomorphic controls on the diversity and patterns of fluvial forms along longitudinal profiles. CATENA 203:105329. https://doi.org/10.1016/j.catena.2021.105329

Kondolf GM, Montgomery DR, Piegay H, Schmitt L (2003) Geomorphic classification of rivers and streams. In: Kondolf GM, Piegay $\mathrm{H}$ (eds) Tools in fluvial geomorphology. Wiley, Chichester, pp 171-204

Kuo CW, Brierley GJ (2013) The influence of landscape configuration upon patterns of sediment storage in a highly connected river system. Geomorphology 180:255-266. https://doi.org/10.1016/j.geomorph.2012.10.015

Latrubesse EM, Stevaux JC, Sinha R (2005) Tropical rivers. Geomorphology 70(3-4):187-206. https://doi.org/10.1016/j.geomorph.2005.02.005

Marcal M, Brierley G, Lima R (2017) Using geomorphic understanding of catchment-scale process relationships to support the management of river futures: Macaé Basin, Brazil. Appl Geogr 84:23-41

Meitzen KM, Doyle MW, Thoms MC, Burns CE (2013) Geomorphology within the interdisciplinary science of environmental flows. Geomorphology 200:143-154

Mines and Geosciences Bureau (MGB) (2010) Geology and mineral resources of the Philippines, 2nd edn. Mines and Geosciences Bureau, Manila

Montgomery DR, Foufoula-Georgiou E (1993) Channel network source representation using digital elevation models. Water Resour Res 29(12):39253934. https://doi.org/10.1029/93WR02463 
Nanson GC (1986) Episodes of vertical accretion and catastrophic stripping: a model of disequilibrium floodplain development. Geol Soc Am Bull 97:1467-1475

Nardini A, Yepez S, Zuniga L, Gualtieri C, Bejarano MD (2020) A computer-aided approach for River Styles-inspired characterization of large basins: the Magdalena River (Colombia). Water 12:1147. https://doi.org/10.3390/ w12041147

National Mapping and Resource Information Authority (NAMRIA) (2010) National land cover mapping. http://www.namria.gov.ph/download.ph. Accessed 17 Dec 2019

Paringit EC, Pascua C (eds) (2017) LiDAR surveys and flood mapping of Bacarra River. University of the Philippines Training Center for Applied Geodesy and Photogrammetry, Quezon City, p 250

Paz-Alberto AM, Sison MJM, Bulaong EP, Pakaigue MA (2016) Remote sensing application of the geophysical changes in the coastlines and rivers of Zambales, Philippines. Int Arch Photogramm Remote Sens Spat Inf Sci. p. 41

Paz-Alberto AM, Bulaong EP, Lao RB, Salvador NC, Raneses EV (2017) Remote sensing in detection of geophysical changes in Talisay River, Bataan, Philippines. In: Fifth international conference on remote sensing and geoinformation of the environment (RSCy2017), 104441C

Petit F, Gob F, Houbrechts G, Assani AA (2005) Critical specific stream power in gravel-bed rivers. Geomorphology 69:92-101. https://doi.org/10.1016/j. geomorph.2004.12.004

Philippine Atmospheric, Geophysical and Astronomical Services Administration (PAGASA) (2019) http://bagong.pagasa.dost.gov.ph/climate/clima te-data. Accessed 16 Dec 2019

Philippine Institute of Volcanology and Seismology (PHIVOLCS) (2015) Distribution of active faults and trenches in the Philippines map. https://www. phivolcs.dost.gov.ph/index.php/earthquake/earthquake-generators-ofthe-philippines. Accessed 20 July 2021

Rhoads B (2020) River dynamics: geomorphology to support management. Cambridge University Press, Cambridge. https://doi.org/10.1017/97811 08164108

Rimando RE, Rimando JM (2020) Morphotectonic kinematic indicators along the Vigan-Aggao Fault: the western deformation front of the Philippine Fault Zone in Northern Luzon, the Philippines. Geosciences 10(2):83. https://doi.org/10.3390/geosciences10020083

Rinaldi M, Surian N, Comiti F, Bussettini M (2013) A method for the assessment and analysis of the hydromorphological condition of Italian streams: the morphological quality index (MQI). Geomorphology 180-181:96-108. https://doi.org/10.1016/j.geomorph.2012.09.009

Rinaldi M, Surian N, Comiti F, Bussettini M (2015) A methodological framework for hydromorphological assessment, analysis and monitoring (IDRAIM) aimed at promoting integrate driver management. Geomorphology. https://doi.org/10.1016/j.geomorph.2015.05.010

Rinaldi M, Gurnell A, González del Tánago M, Bussettini M, Hendriks D (2016) Classification of river morphology and hydrology to support management and restoration. Aquat Sci 78:17-33. https://doi.org/10.1007/ s00027-015-0438-z

Schwanghart W, Scherler D (2014) TopoToolbox 2-MATLAB-based software for topographic analysis and modeling in Earth surface sciences. Earth Surf Dyn 2:1-7. https://doi.org/10.5194/esurf-2-1-2014

Schwanghart W, Scherler D (2017) Bumps in river profiles: uncertainty assessment and smoothing using quantile regression techniques. Earth Surf Dyn 5:821-839. https://doi.org/10.5194/esurf-5-821-2017

Sear DA, Newson MD, Brookes A (1995) Sediment related river maintenance: the role of fluvial morphology. Earth Surf Process Landf 20:629-647

Sinha R, Latrubesse EM (2020) Geomorphology of fluvial systems: focus on tropical rivers. Geomorphology 363:107223. https://doi.org/10.1016/j. geomorph.2020.107223

Tadaki M, Brierley G, Cullum C (2014) River classification: theory, practice, politics. Wiley Interdiscip Rev Water 1:349-367. https://doi.org/10.1002/ wat2.1026

Tolentino PLM, Poortinga A, Kanamaru H, Keesstra S, Maroulis J, David CPC, Ritsema CJ (2016) Projected impact of climate change on hydrological regimes in the Philippines. PLoS ONE 11(10):e0163941. https://doi.org/10. 1371/journal.pone.0163941

Wyrick JR, Pasternack GB (2014) Geospatial organization of fluvial landforms in a gravel-cobble river: beyond the riffle-pool couplet. Geomorphology 213:48-65

\section{Publisher's Note}

Springer Nature remains neutral with regard to jurisdictional claims in published maps and institutional affiliations.

\section{Submit your manuscript to a SpringerOpen ${ }^{\odot}$ journal and benefit from:}

- Convenient online submission

- Rigorous peer review

- Open access: articles freely available online

- High visibility within the field

- Retaining the copyright to your article

Submit your next manuscript at $\boldsymbol{\Delta}$ springeropen.com 